\title{
A Framework for Examining Assessment Literacy of Preservice Teachers*
}

\author{
Lim Hooi Lian, Wun Thiam Yew \\ Universiti Sains Malaysia, Penang, Malaysia
}

\begin{abstract}
It was well documented from some previous studies that school teachers' assessment skills are generally feeble. Research findings stated that the problem of inaccurate assessment of students was mainly due to unacceptably low levels of assessment literacy among preservice teachers and administrators in schools. Therefore, a comprehensive understanding of preservice teachers' assessment literacy is crucial. Selecting an assessment method for assessing students' skills and knowledge remains a less active task in school where attempts to revamp existing assessment methods had been hindered by the lack of knowledge, skills, and proper guidance. Thus, in this paper, a framework to examine preservice teachers' assessment literacy level pertaining to the competence in selecting of assessment methods had been proposed. Four steps of the assessment planning stage and the Structure of Observed Learning Outcome (SOLO) model had been adapted to develop the assessment framework. Researchers hypothesized that preservice teachers could exhibit three levels of assessment literacy based on the cognitive development model. The three levels include unistructural, multistructural, and relational.
\end{abstract}

Keywords: assessment literacy, selecting of assessment method, Structure of Observed Learning Outcome (SOLO) model

\section{Introduction}

Assessment literacy can be defined as the solid and sound educational assessment knowledge and skills that required by teachers in assessing students' mastery of learning outcome. Thus, it is one of the most important responsibilities of teachers in classroom teaching and learning (Mertler \& Campbell, 2005; Popham, 2006; Volante \& Fazio, 2007). According to Stiggins (1999), the effectiveness of teaching methods used in classroom is reflected by the quality of the assessments used. Therefore, the results gathered from classroom assessments should be reliable and valid (Brookhart, 1999).

In recent years, Malaysian government's devotion has moved to the implementation of new assessment system, namely, school-based assessment (pentaksiran berasaskan sekolah) in primary and secondary schools level. Therefore, there has been a growth of expectations concerning school teachers' assessment knowledge and skills. School teachers were required to implement continuously school level assessment professionally and creatively that align with the learning outcomes in the curriculum standards as a means of improving students' learning ability and performance.

\footnotetext{
*Acknowledgment: This paper is made possible with funding from the Short Term Grant of Universiti Sains Malaysia, Penang, Malaysia.

Lim Hooi Lian, Ph.D., senior lecturer, School of Educational Studies, Universiti Sains Malaysia.

Wun Thiam Yew, Ph.D., senior lecturer, School of Educational Studies, Universiti Sains Malaysia.
} 
Yet, previous studies had demonstrated that school teachers' assessment literacy is generally feeble (Brookhart, 2001; Campbell, Murphy, \& Holt, 2002; Suah, 2012). Stiggins (2001) and Suah (2012) stated that the issue of inaccurate and invalid educational assessment was mainly due to the unacceptably low levels of assessment literacy among preservice teachers and school administrators'. As a result, it has prevented the students from reaching their full potential.

Furthermore, it was well documented from some previous studies that school teachers do not follow the fundamental principles of educational assessment recommended by experts when assessing students' learning quality (Brookhart, 1993; Frary, Cross, \& Weber, 1993; Suah, 2012). According to the research findings, the problems of lack of teachers' consensus on deciding the most beneficial and suitable assessment practices, limited assessment training, lack of assessment knowledge and skills may result in the teachers' variation in implementing the classroom assessment (Stiggins, Frisbie, \& Griswold, 1989; Suah, 2012).

In Malaysia, a few researches had been done regarding teachers' assessment practices and assessment literacy (Asri, 2007; Chang, 1988; Rohaya \& Mohd Najid, 2008; Suah 2012). However, the main focus was more on inservice teachers. There is still fairly little research related to the investigating of assessment skills and knowledge among preservice teachers. This focus of research should logically begin in school of education or faculty of education, because they play the vital role to provide the future teachers with their fundamental knowledge and skills of educational assessment and evaluation. Furthermore, in the long run, a detail and comprehensive understanding of preservice teachers' assessment literacy levels serves the twofold purpose of notifying the future direction of teacher education reforms and the enhancement of teachers' professional development quality.

\section{Assessment Literacy}

"Assessment literacy" is central to this study. Therefore, it is vital that this terminology should be defined or otherwise described clearly. A simple definition is offered by Stiggins (1995) who indicated that "Assessment literates mean the ability to detect the differences between sound and unsound assessment." He specified that assessment-literate educators should be able to know: (a) the content and learning outcome to be assessed; (b) the purpose of having assessment; (c) the best way to assess the students' skills and knowledge; (d) the development of quality instrument to assess students' performance; (e) the potential problems with the assessment; (f) the prevention of the problem; and (g) the awareness of the potential negative consequences of poor, inaccurate assessment (Stiggins, 1995).

According to the standards for teacher competence in the Educational Assessment of Students (American Federation of Teachers, National Council on Measurement in Education, National Education Association, 1990), there are seven standards for teacher competence in classroom assessment. Teachers should be skilled in:

1. Choosing assessment methods that are suitable for the learning outcomes to be assessed;

2. Developing assessment instrument that are suitable for the learning outcomes to be assessed;

3. Administering, scoring, and interpreting the assessment findings of both externally-produced and teacher-produced assessment;

4. Using assessment results perceptively when making decisions about students' learning, teachers' teaching, school development, program, or curriculum;

5. Developing the reliable and valid grading procedures; 
6. Communicating and reporting efficiently the assessment results to students, parents, school administers, and other educators;

7. Recognizing the illegal, unethical, inappropriate uses of assessment information and methods of assessment.

Meanwhile, Rohaya and Mohd Najib (2008) defined assessment literacy as the competency of teachers' knowledge in the assessment field. Based on such knowledge, teachers can practice the principles, procedures, strategies, and assessment methods appropriately to assist the learning process. Thus, it will enable teachers to make more accurate and fair decision about students, curriculum, and educational programs. There are five main constructs of assessment literacy as follows:

(a) Literacy concept;

(b) Measurement method;

(c) Testing;

(d) Scoring and grading;

(e) Statistics and reporting.

Based on the different perspectives of defining assessment literacy, it can be concluded that there exists no definite definition for assessment literacy as it can be viewed from different perspectives. A university professor's view of assessment literacy is not usually the same as the view of a professional test developer, a school teacher or an expert in educational assessment. It might probably involve vastly different skills and knowledge. In a simple word, the assessment literacy embodies a wide matrix of skills and knowledge which vary significantly from population to population. Nevertheless, the competence with respect to the selecting of assessment methods becomes one of the most important dimensions in their definitions of the assessment literacy concept.

Selecting an assessment method for assessing students' skills and knowledge remains a less active task in school where attempts to revamp existing assessment methods had been hindered by the lack of knowledge, skills, and proper guidance (Suah, 2012). Thus, in this study, based on our experiences and expertise as both educators and trainers, we proposed a framework to assess preservice teachers' assessment literacy level pertaining to the competence in selecting of assessment methods.

\section{Assessment Literacy: Selecting Assessment Method}

No single assessment method is universally appropriate and valid for every types of learning outcomes. For instance, if an intended learning outcome for an educational measurement and evaluation course is "to be able to develop an assessment task to assess students' language communication skill." It is inappropriate to assess this learning outcome by constructing essay item test. Similarly, most learning outcomes involve psychomotor skills cannot be assessed by paper and pencil test. In order to align assessment with a particular type of learning outcome, teachers need to be skillfull in selecting an appropriate method of assessment.

According to Stiggins, Arter, Chappuis, and Chappuis (2004), in all assessment development cycle, assessment planning stage involved four steps, namely: (a) determine the intended uses of an assessment; (b) identify the learning outcomes to be assessed; (c) select the proper assessment method; and (d) determine the relative importance of each learning target. They stated that the quality and valid assessments arise from clear, specific, and measureable learning outcome. In other words, the clear learning outcome is important because different learning outcomes require different assessment methods. At this point, teachers need to follow the four steps as follows: 
(a) List the major learning targets that the teachers will be teaching;

(b) Identify the prerequisite sub-targets by clarifying and listing the learning outcomes, as needed;

(c) Classify the learning outcomes into different domains;

(d) Deciding assessment method to be selected.

In this study, the four steps identified by Stiggins et al. (2004) were adapted to assess the preservice teachers' assessment literacy pertaining to the competence in selecting of assessment methods as shown in Figure 1.
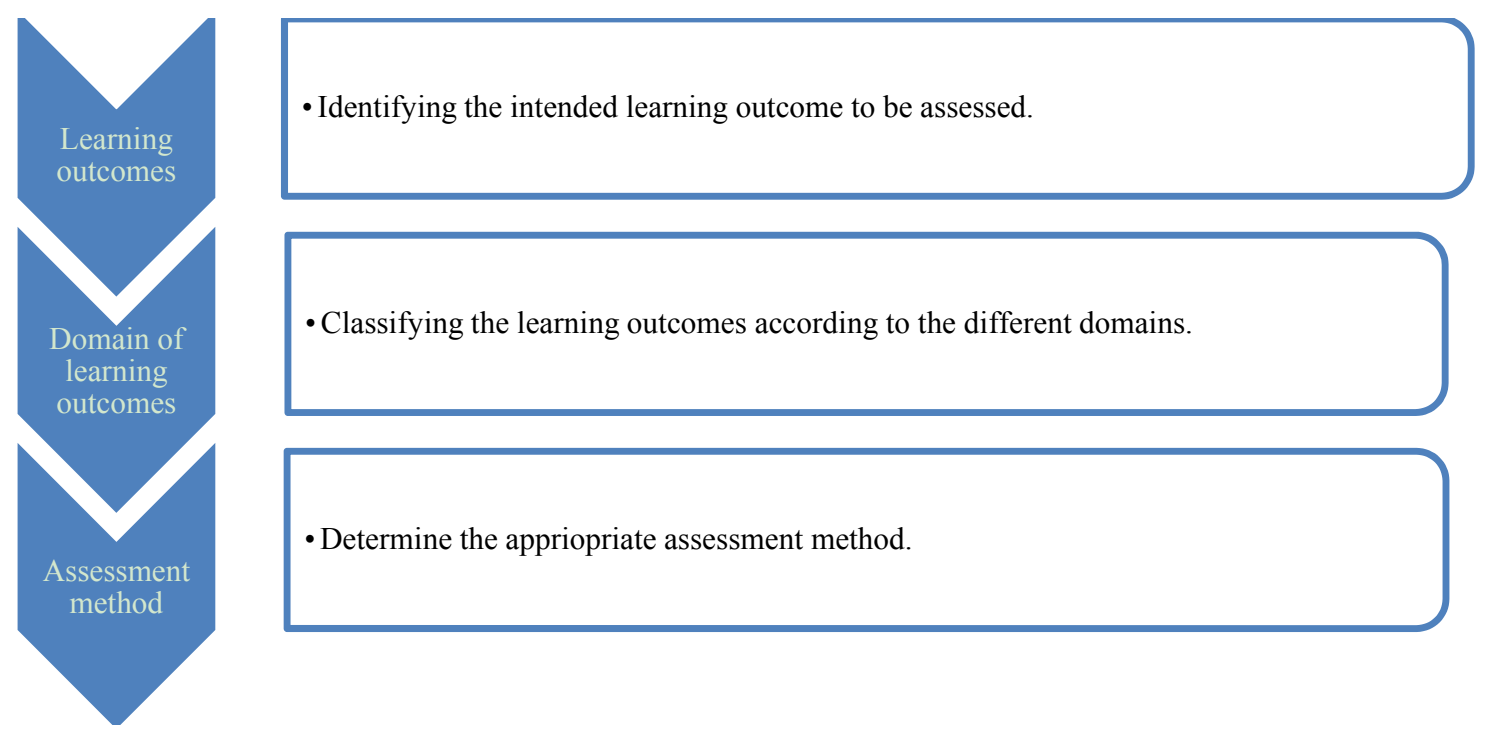

Figure 1. Assessment literacy in selecting of assessment method.

The Structure of the Observed Learning Outcome (SOLO) model, a cognitive psychology model which is developed by Biggs and Collis (1982), was used to assess preservice teachers' assessment literacy pertaining to the competence in selecting the methods of assessment. The SOLO model highlights more on the internal process and analyzing "how" a task is responded and solved rather than the final solution is correct or incorrect. Researchers hypothesized that preservice teachers could exhibit three levels of assessment literacy. Thus, the theoretical framework will be developed along with the expected preservice teachers' assessment literacy pertaining to the competence in selecting of assessment methods based on the SOLO mode, levels, namely, unistructural, multistructural, and relational. The detail description of important concept and characteristics of the SOLO model and its application has been discussed as follows.

\section{SOLO Model}

Based on the SOLO model, when a learner answers a task, his/her responses can be summarized into levels (Biggs \& Collis, 1982; Biggs \& Collis, 1989; Chick, 1988; Chick, 1998; Wilson \& Iventosch, 1988; Wongyai \& Kamol, 2004; Wilson \& Chavarria, 1993; Aoyama, 2007; Quinn, Pegg, \& Debra, 2009). That is, it assumes a latent hierarchical and cumulative cognitive dimension in analysing the learners' structure responses. The SOLO model found that the structure responses generally can be classifying into five levels, ranging from prestructural to extended abstract; these are explained in detail as follows:

1. Prestructural: The learner fails to engage in the task given. He/she gives a response without even dealing with the task. Most probably, the leaner does not understand the point of task. 
2. Unistructural: The learner picks up one or a few of relevant information provided to give a response. The information is available directly from story of the problem or from the diagram given. That is, a quick closure (answer) is achieved on the basis of minimal use of information provided.

3. Multistructural: The learner picks up more relevant information given to give response. The information may use as a procedure; a set of directions or guidelines are followed in order to response the task. That is, the information are not yet been integrated.

4. Relational: The learner is able to assimilate and integrate all aspects of information provided with each other to reach a conclusion. The information given is inadequate to response the task directly. It must be wisely integrated to gain the solution.

5. Extended abstract: The learner is able to apply the concept or theory into a novel and more complex situation. This level normally may allow the generalization of the conclusion or solution to a new situation or more complex pattern.

At the unistructural and multistructural levels, the learner may only need to encode the information given in the problem situation and use straightly to response the task. The structure response for both levels only includes one or more pieces of information provided in the problem situation. There is direct and concrete relationship between the task and the information given in the problem situation. Whereas, at the relational or extended abstract levels, the learner needs to make a generalization or conclusion within the information given or application of the abstract principle into a more complex situation. Thus, there is a close relationship between the information given and the task. In short, the four responses levels represent both an increase in the application of the information provided in the task and an increase in the complexity of structure response.

Table 1

The Framework on the Characteristics of Assessment Literacy Pertaining to the Competence in Selecting of Methods of Assessment

Professor John taught a civil engineering course at a university located in rural area. He wanted to determine whether his 250 final year students were able to analyze, generalize, and evaluate engineering knowledge in the construction of highways. In addition, he also attempted to find out about the students' abilities in integrating the information technology theory with their engineering knowledge.

\begin{tabular}{|c|c|c|}
\hline Level of task & Task & Description \\
\hline Unistructural & $\begin{array}{l}\text { What is the intended learning outcome to } \\
\text { be assessed by Professor John? }\end{array}$ & $\begin{array}{l}\text { This level requires the response based on } \\
\text { referring directly to one piece of concrete } \\
\text { information in the task. } \\
\text { The task requires the ability of the } \\
\text { understanding of intended learning } \\
\text { outcome. The task can be responded based } \\
\text { on the concrete information given; that is, } \\
\text { identify an intended learning outcome } \\
\text { from the given information. }\end{array}$ \\
\hline Multistructural & $\begin{array}{l}\text { Classify the intended learning outcomes } \\
\text { into domains. }\end{array}$ & $\begin{array}{l}\text { The task requires the given information } \\
\text { are handled serially. That is, identify all } \\
\text { the intended outcomes and do the } \\
\text { classification into domains. The } \\
\text { information given in the task is still used } \\
\text { directly. }\end{array}$ \\
\hline Relational & $\begin{array}{l}\text { Which assessment method is the most } \\
\text { appropriate that can be proposed to } \\
\text { Professor John? Give reason to support } \\
\text { your response. }\end{array}$ & $\begin{array}{l}\text { The task requires the integration of all } \\
\text { given information to make a conclusion. } \\
\text { The learner has to consider all the given } \\
\text { information in order to decide the most } \\
\text { appropriate assessment method. }\end{array}$ \\
\hline
\end{tabular}


Combination of the SOLO model and superitem format had been developed (Collis, Romberg, \& Jurdak, 1986; Lam \&Foong, 1998; Wilson \& Iventosh, 1988) to generate an alternative assessment framework for monitoring the growth of learner's cognitive ability in solving problems. In the superitem format, it consists of a problem situation and three to four different complexity levels of questions related to it. The problem situation is often represented by text, diagram, or graphic. While the questions represent the levels of cognitive reasoning defined by the SOLO model which includes unistructural, multistructural, relational, and extended abstract. Thus, a right response to the specify level of question (three questions indicate three levels) within superitem would indicate the cognitive ability at a certain level reflected in the SOLO model.

The following discussion develops an assessment literacy task that can be used to assess preservice teachers' assessment literacy pertaining to the competence in selecting of methods of assessment. It provides a developmental pattern that acquires a better understanding in the way described in Table 1 .

\section{Conclusion}

In this study, a more systematic framework had been presented to assess the competence with respect to the selection of assessment methods. Teachers need to be skilled in selecting more appropriate assessment methods by considering main factors that the most significantly influence upon the selection of different assessment methods, specifically the intended learning outcomes of the topics to be assessed. The model is simple to apply in any dimension of assessment literacy. Besides, it can be used as a tool for promoting change in both preservice teachers' and inservice teachers' assessment literacy and practices.

\section{References}

American Federation of Teachers, National Council on Measurement in Education, National Education Association. (1990). Standards for teacher competence in educational assessment of students. Retrieved July 12, 2014, from http://www.lib.muohio.edu/edpsych/stevens_stand.pdf

Aoyama, K. (2007). Investigating a hierarchy of students' interpretation of graphs. International Electronic Journal of Mathematics Education, 2(3), 298-318.

Asri, S. (2007). Amalanpen taksiran pengajaran danpem belajaran di sekolah-sekolah menengah bestari Negeri Johor Darul Takzim (Teaching and learning assessment practice in Bestari secondary school, Johor State) (Unpublished Ph.D. dissertation, Universiti Teknologi Malaysia, Skudai, Malaysia).

Biggs, J. B., \& Collis, K. F. (1982). Evaluating the quality of learning: The SOLO taxonomy (Structure of the observed learning outcome). New York: Academic Press.

Biggs, J. B., \& Collis, K. F. (1989). Towards a model of school-based curriculum development and assessment using the SOLO taxonomy. Australians Journal of Education, 33(2), 151-163.

Brookhart, S. M. (1993). Teachers' grading practices: Meaning and values. Journal of Educational Measurement, 30, $123-142$.

Brookhart, S. M. (1999). The art and science of classroom assessment: The missing part of pedagogy. Washington, D.C.: ERIC Clearinghouse on Higher Education and Office of Educational Research and Improvement.

Brookhart, S. M. (2001). The standards and classroom assessment research. Paper presented at The Annual Meeting of the American Association of Colleges for Teacher Education, Dallas, T.X.. (ERIC Document Reproduction Service No. ED451189)

Campbell, C., Murphy, J. A., \& Holt, J. K. (2002, October). Psychometric analysis of an assessment literacy instrument: Applicability to preservice teachers. Paper presented at The Annual Meeting of the Mid-Western Educational Research Association, Columbus, O.H..

Chang, S. F. (1988). Teachers' assessment pratices: Assessing phase LL pupils' progress in KBSR English (Unpublished master's thesis, Universiti Malaya, Petaling Jaya).

Chick, H. L. (1988). Student responses to polynomial problem in the light of the SOLO taxonomy. Australian Senior Mathematics Journal, 2(2), 91-110. 
Chick, H. L. (1998). Cognition in the formal modes: Research mathematics and the SOLO Taxonomy. Mathematics Education Research Journal, 10(2), 4-26.

Collis, K. F., Romberg, T. A., \& Jurdak, M. E. (1986). A technique for assessing mathematical problem-solving ability. Journal for Research in Mathematics Education, 17(3), 206-221.

Earl, L., \& Katz, S. (2004). Rethinking classroom assessment with purpose in mind. Retrieved May 4, 2012, from http://www.wenp.ca/assessment/ rethink.pdf

Frary, R. B., Cross, L. H., \& Weber, L. J. (1993). Testing and grading practices and opinions of secondary teachers of academic subjects: Implications for instruction in measurement. Educational Measurement: Issues and Practice, 12(3), 23-30.

Lam, P., \&Foong, Y. Y. (1998). Assessment of mathematics structure of learning outcome proficiency attainment level using hierarchical items in testlets. Educational Research Quarterly, 27(2), 3-15.

Mertler, C. A., \& Campbell, C. (2005, April). Measuring teachers' knowledge and application of classroom assessment concepts: Development of the assessment literacy inventory. Paper presented at The Meeting of the American Educational Research Association, Montreal, Quebec, Canada.

Popham, W. J. (2006). Needed: A dose of assessment literacy.Educational Leadership, 63, 84-85.

Quinn, F., Pegg, J., \& Debra, P. (2009). First-year Biology students' understandings of meiosis: An investigation using a structural theoretical framework. International Journal of Science Education, 31(10), 1279-1305.

Stiggins, R., Arter, J. Chappuis, J., \& Chappuis, S. (2004). Classroom assessment for student learning. Doing it right-using it well. Retrieved July 8, 2014, from http://www-tc.pbs.org/teacherline/courses/inst325/docs/inst325_stiggins.pdf

Stiggins, R. J. (1995). Assessment literacy for the 21st century. Phi Delta Kappan, 77(3), 238-245.

Stiggins, R. J. (1999). Are you assessment literate? The High School Journal, 6(5), 20-23.

Stiggins, R. J. (2001). The unfulfilled promise of classroom assessment. Educational Measurement: Issues and Practice, 20(3), $5-15$.

Stiggins, R. J., Frisbie, D. A., \& Griswold, P. A. (1989). Inside high school grading practices: Building a research agenda. Educational Measurement: Issues and Practice, 8(2), 5-14.

Suah, S. L. (2012). Analisis model literasid anamal an pentaksiran guru sekolah sertaka jiantentan gjurangan tarakeduanya (Analysis of literacy model and assessment practices of school teachers and study of the culture gap) (Unpublished Ph.D. dissertation, School of Educational Studies, Universiti Sains Malaysia).

Rohaya, T., \& Mohd Najib, N. G. (2008, November 25-27). Pembina and anpenges ahan instrument bagimengu kurtahap literasipenta ksiran guru sekol ahmenengah di Malaysia (Development and validation of instrument to measure Malaysian secondary school teachers' assessment literacy level). In Proceedings of Seminar Penyelidikan Pendidikan Pascaljazah, Universiti Teknologi Malaysia.

Volante, L., \& Fazio, X. (2007). Exploring teacher candidates' assessment literacy: Implications for teacher education reform and professional development. Canadian Journal of Education, 30, 749-770.

Watson, J., Chick, H., \& Collis, K. (1988). Applying the SOLO taxonomy to error on area problems. In Proceeding of the 12th Biennial Conference of the Australian Assossiation of Mathematics Teachers (pp. 260-281), Newcastle.

Wilson, M., \& Iventosch, L. (1988). Using the partial credit model to investigate responses to structured subtest. Applied Measurement in Education, 1(4), 319-334.

Wongyai, P., \& Kamol, N. (2004). A framework in characterizing lower secondary school students' algebraic thinking. Retrieved December 23, 2004, from http://www.icme-organisers.dk/tsg09/PiyavadeeWongyai.pdf 